\title{
Fracture Resistance of Groundnut (cv. SAMNUT 11) Kernel under Quasi-Static Compression Loading
}

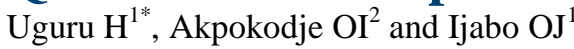

${ }^{1}$ Department of Agricultural and Environmental Engineering, University of Agriculture, Makurdi, Nigeria

${ }^{2}$ Department of Civil Engineering Technology, Delta State Polytechnic, Ozoro, Nigeria

DOI: $10.36347 /$ sjet.2020.v08i01.001

| Received: 07.12.2019 | Accepted: 12.12.2019 | Published: 11.01.2020

*Corresponding author: Uguru $\mathrm{H}$

Abstract

Original Research Article

In this study, quasi-static compression test was performed on SAMNIT 11 groundnut kernels to evaluate the effect of loading rate; kernel orientation and size, on some of its mechanical behaviours (rupture force, rupture energy, toughness and rupture power). The SAMNUT 11 groundnut kernels used for this study were categorized into three sizes (large, medium and small) and compressed along three orientations (X- Y- and Z- axis), at three loading rates $(15,20$ and $25 \mathrm{~mm} / \mathrm{min})$. The $\mathrm{X}$ - axis is the plane perpendicular to the suture line; $\mathrm{Y}$ - axis is in the plane containing the suture line; while Z-axis is the longitudinal axis through the suture line. Results obtained from the quasi-static compression test showed that loading rate had significant $(\mathrm{p} \leq 0.05)$ effect on all the mechanical behaviours studied. In contrast, the kernel orientation and size did not significantly $(\mathrm{p} \leq 0.05)$ affect the rupture energy of the groundut kernel. The results further depicted that the mechanical behaviours values were highest when the kernels were compressed at $15 \mathrm{~mm} / \mathrm{min}$ along the $\mathrm{X}$ - axis. From the results, the highest rupture energy $(0.116 \mathrm{Nm})$ was recorded when the large kernel was compressed along the $\mathrm{X}$-axis, at a loading rate of $15 \mathrm{~mm} / \mathrm{min}$, while the least rupture energy $(0.02 \mathrm{Nm})$ was recorded when the small kernel was compressed along the $\mathrm{Z}$-axis at a loading rate of $25 \mathrm{~mm} / \mathrm{min}$. On average, the large groundnut kernels required about $38 \%$ greater force to rupture when compared with the small kernels. In addition, the kernel toughness decreased with increase of the kernel size. These results could be useful in modification of existing groundnut processing (milling) equipment.

Keywords: SAMNUT 11 groundnut, loading orientation, loading rate, rupture power, size.

Copyright @ 2020: This is an open-access article distributed under the terms of the Creative Commons Attribution license which permits unrestricted use, distribution, and reproduction in any medium for non-commercial use (NonCommercial, or CC-BY-NC) provided the original author and source are credited.

\section{INTRODUCTION}

Groundnut (Arachis hypogaea L.) is a leguminous oilseed crop cultivated in nearly 100 countries of the world. According to the Food and Agriculture Organization statistics, about 47 million tonnes of groundnut where produced in the world in 2017. Currently, Nigeria ranks the $8^{\text {th }}$ position in groundnut production in the world, producing about 2.5 million tonnes of groundnut in 2017 [1]. Since 1990, the International Crops Research Institute for the SemiArid Tropics (ICRISAT), and other research centres in the Africa continent have developed and tested about 30 improved (disease resistant and improved yield) groundnut varieties [2]. Early maturing groundnut varieties are more suitable for areas with shorter annual rainfall, while late - maturing types will perform better in areas with longer rainfall duration [3]. The nutritional value of groundnut kernel is highly influenced by its cultivar, soil type, local climatic condition, harvesting time, farming methods, etc. [4]. Among the plant family, legumes are the most utilized as an alternative source of protein; human consumption of legumes has been increasing recently since the seeds are regarded as a source of beneficial nutrients [5]. Groundnut kernels are consumed directly (raw or cooked) by human beings, or processed into refined products like groundnut oil, groundnut butter, groundnut cake, etc. [6].

The physical characteristics and mechanical properties of agricultural materials are essential in the design and development of their related handling, processing and storage types of machinery. Knowledge of failure properties of agricultural properties is necessary for the design of their storage and handling systems. In addition, the knowledge of rupture parameters of agricultural products under compression loading is vital for the design of their milling and crushing machines. Angle of repose plays an important role in designing the equipment for solid flow and storage. Knowledge of the frictional properties is 
valuable in designing machines effective in dehulling and packaging [7]. The mechanical response of kernel, seed and nut to impact loading or a static compressional loading is highly influenced on the direction of the load's application to the struts, beams, or cantilevers within the tissue $[8,9]$. During harvest and postharvest operations, fruits and kernels go through several static and dynamic pressures (e.g. high-speed impacts), which caused bruises, crushes and cracks that increase their susceptibility to deterioration during storage $[10,11]$.

Several researchers have investigated the mechanical properties of fruits and nuts under quasistatic compression loading, with respect to their sizes and orientations. Guner et al. [12] evaluated the mechanical behaviour of hazelnut under compression loading under two loading orientations; and reported that the highest rupture energy $(812.90 \mathrm{Nmm})$ was obtained when the nut was loaded along the axial axis, while the lowest $(488.60 \mathrm{Nmm})$ rupture energy was obtained when the nut was loaded along the longitudinal axis. Uguru and Nyorere [9] reported that the failure force the groundnut kernels increased (from $41.28 \mathrm{~N}$ to $75.37 \mathrm{~N}$ ) with an increase in the kernel size; but on the contrast, the failure force decreased from $75.37 \mathrm{~N}$ to $34.42 \mathrm{~N}$, as the loading rate increased from $15 \mathrm{~mm} / \mathrm{min}$ to $25 \mathrm{~mm} / \mathrm{min}$. Additionally, Altuntas et al. [13] investigated the mechanical behaviours (rupture force, specific deformation, rupture energy and toughness) of plum fruits during compression, at a different orientation. They observed that the rupture energy and rupture power values of the plum fruits when compressed along the Y- orientations were highest when compared to the results obtained when the fruits were tested along the $\mathrm{X}$ - and Z-orientations. Sadowska et al. [14] stated that there was a clear tendency towards an increase in failure force with an increase in seed size, despite the accessions and varieties. Uyeri and Uguru [15] reported that the force required for initiating the rupture of SAMNUT 10 groundnut kernel increased from 37.21 to $76.10 \mathrm{~N}$, as the kernel size increased from small to large size. In addition, Uyeri and Uguru [15] observed that the energy absorbed by SAMNUT 10 groundnut kernel at rupture point increased from 0.021 to $0.054 \mathrm{Nm}$, as the kernel size increased from small and large kernel. Ijabo et al. [16] investigated the cracking force of groundnut, Bambara nut (Voandzeia subterranean) and African yam bean (sphenostylis stenocarpa) under quasi-static compression loading. They reported that the groundnut seeds had the least cracking force $(8.965 \mathrm{~N})$, which was widely followed by the African yam bean is $(24.285 \mathrm{~N})$; while the bambara nut pod had the highest cracking force $(35.37 \mathrm{~N})$.

Despite the above-mentioned research accounts, and increase in groundnut production in Nigeria, there is still a dearth of information on the mechanical properties of SAMNUT 11 kernels, which will be helpful in modification of existing processing and storage systems. Therefore, the objective of this study was to determine the effect of loading rate, loading orientation and kernel size on the average rupture force, rupture energy, toughness, and rupture power of SAMNUT 11 kernels in order to provide useful data for the design and fabrication of new groundnut processing equipment.

\section{MATERIALS AND METHODS Study Setting}

This study was carried out at the Research Farm of the Delta State Polytechnic, Ozoro, Nigeria. The area is located at Latitude $5^{\circ} 32 \mathrm{~N}$ and $5^{\circ} 33 \mathrm{~N}$ and Longitude $6^{\circ} 14 \mathrm{E}$ and $6^{\circ} 15 \mathrm{E}$ in southern Nigeria. During the experimental period, the average temperature of the area was $28^{\circ} \mathrm{C}$, according to data obtained from the school metrological station.

Soil analysis was conducted on soil samples randomly collected from the experimental area where the groundnut was planted. The physicochemical analysis of soil samples was done in accordance with standard recommended procedures [17, 18], and the results are presented in Table 1.

Table-1: Physicochemical properties of the study area soil sample

\begin{tabular}{|l|l|l|}
\hline Parameter & Unit & Level \\
\hline Particle size distribution & & \\
\hline Sand & $\%$ & 40.3 \\
\hline Silt & $\%$ & 35.6 \\
\hline Clay & $\%$ & 24.1 \\
\hline Chemical analysis & & \\
\hline Soil pH & & 7.75 \\
\hline Total nitrogen & $(\mathrm{mg} / \mathrm{kg})$ & 4.119 \\
\hline Available Phosphorus & $(\mathrm{mg} / \mathrm{kg})$ & 9.137 \\
\hline Copper & $(\mathrm{mg} / \mathrm{kg})$ & 4.911 \\
\hline Nitrate & $(\mathrm{mg} / \mathrm{kg})$ & 8.223 \\
\hline Sodium & $(\mathrm{mg} / \mathrm{kg})$ & 450.748 \\
\hline Extractable Potassium & $(\mathrm{mg} / \mathrm{kg})$ & 687.585 \\
\hline
\end{tabular}




\section{Plant of Interest}

SAMNUT 11 kernels, a high yield groundnut variety were obtained from ICRISAT, Kano State, Nigeria, was used in this study.

\section{Groundnut Cultivation}

The kernels were planted in the research farm of Delta State Polytechnic, Ozoro, under organic farming method. Poultry waste and other organic materials were incorporated into the soil four weeks before the groundnut were planted. This is because groundnut does not respond well to direct fertilization [3]. During the growing period, disease outbreak was not registered on the farm. The groundnut was harvested at full maturity age, i.e. when about $80 \%$ of the kernels were plump and showed their true colour [3].

\section{Samples Collection and Preparation}

The groundnut samples were harvested at maturity age, sun-dried on a platform for three days before threshing, to remove the pods from the plants.
Then the pods were separated from foreign materials and shelled manually to obtain the kernels. In other to achieve uniform lower moisture content, the kernels were again sun-dried for another eight days. Lastly, the sun-dried kernels were inspected manually to remove pest-infested kernels, premature kernels and other contaminants.

\section{Physical Characteristics Determination}

The physical characteristics of the selected groundnut kernels were determined at the agricultural and bio-environmental engineering laboratory, Delta State Polytechnic, Ozoro, Nigeria. Each kernel principal dimensions (Length (L), width (W), and Thickness (T)) were measured with a digital vernier caliper, having accuracy of $0.01 \mathrm{~mm}$. These dimensional values were used to determine the size and calculate the volume of each individual kernel. The kernels were categorized into large, medium and small sizes as presented in Table 2. The kernel volume (V) was calculated using Equation 1.

$$
V=\frac{\pi \times L \times W \times T}{6}
$$

Table-2: Groundnut kernels size classification

\begin{tabular}{|l|l|l|l|}
\hline Variety & \multicolumn{3}{|c|}{ Size (mm) } \\
\hline & Small & Medium & Large \\
\hline SAMNUT 11 & $\mathrm{L}<13.5$ & $13.5 \leq \mathrm{L} \leq 23.5$ & $\mathrm{~L}>23.5$ \\
\hline & $\mathrm{W}<8.5$ & $8.5 \leq \mathrm{W} \leq 13.5$ & $\mathrm{~W}>13.5$ \\
\hline & $\mathrm{T}<7.5$ & $7.5 \leq \mathrm{T} \leq 10.5$ & $\mathrm{~T}>10.5$ \\
\hline
\end{tabular}

\section{Mechanical Properties Determination}

The quasi-static compression tests of the SAMNUT 11 groundnut kernels were done at the Material Testing Laboratory of the National Center for Agricultural Mechanization (NCAM), Ilorin, Kwara State, Nigeria. The Universal Testing Machine (Testometric model, series 500-532) equipped with a 50 $\mathrm{KN}$ compression load cell and integrator, with measurement accuracy of $0.001 \mathrm{~N}$ was employed to carry out the mechanical test of the groundnut kernel. During the quasi-static compression test, one kernel was placed at a time under the flat compression tool of the Universal Testing Machine, as shown in Figure 1, and compressed a pre-determined speed. A forcedeformation curve was plotted automatically by the machine in relation to the response of the sample to compression loading [19]. At the end of each test, the following mechanical parameters (rupture, energy and deformation at rupture point) of the sample were calculated were automatically calculated by the integrator of the machine and read from the computer screen. The test was done for three loading rates $(15,20$ and $25 \mathrm{~mm} / \mathrm{min}$ ), three kernel sizes (small, medium and large), and three kernel orientations ( $\mathrm{X}, \mathrm{Y}$ and $\mathrm{Z}$ axes). As recommended by ASABE [20], the mechanical tests were replicated 20 times, and the mean values were recorded.

As shown in Figure 2, the $\mathrm{Y}$-axis is in the plane containing the suture line; $\mathrm{X}$ - axis is the plane perpendicular to the suture line, while $\mathrm{Z}$-axis is the longitudinal axis through the suture [21, 22]. SAMNUT 11 groundnut kernel has the complex nonisotropic system, just like other agricultural products; its size and shape changes continually during compression. Therefore, it is practically difficult to characterize it by simple constants (e.g. stress); consequently, it is necessary to introduce some concepts such as "rupture point" in characterizing it $[23,9]$.

Rupture point of the material correlates to the macroscopic failure of the sample Steffe [24]. The toughness of a groundnut kernel was the energy absorbed by groundnut kernel up to the rupture point; it was calculated as the rupture energy divided by the kernel volume, as shown in Equation 2 [25, 26]. Rupture power required to rupture the kernel was calculated using Equation 3, and the volume of the kernel was calculated using equation 4 .

$T_{o}=\frac{E}{V}$ 
$P=\left(\frac{E \times S}{6000 D}\right)$

$V=\frac{\pi \times L \times W \times T}{6}$

Where:

$\mathrm{T}_{\mathrm{o}}=$ Toughness $\left(\mathrm{mJ} / \mathrm{mm}^{3}\right)$,

$\mathrm{E}=$ Rupture energy or energy absorbed by the kernel

$(\mathrm{Nm})$,

$\mathrm{V}=$ Volume of the kernel $\left(\mathrm{m}^{3}\right)$,

$\mathrm{P}=$ Power $(\mathrm{W})$,

$\mathrm{S}=$ Compression speed $(\mathrm{mm} / \mathrm{min})$

$\mathrm{L}=$ length of the kernel $(\mathrm{mm})$,

$\mathrm{W}=$ width of the kernel $(\mathrm{mm})$,

$\mathrm{T}=$ Thickness of the kernel $(\mathrm{mm})$.

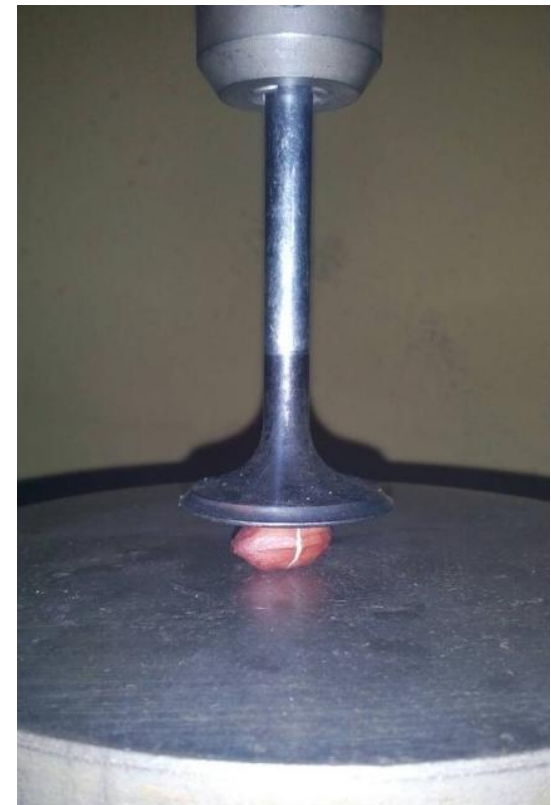

Fig-1: A SAMNUT 11 Groundnut Kernel Undergoing Quasi Static Compression Loading

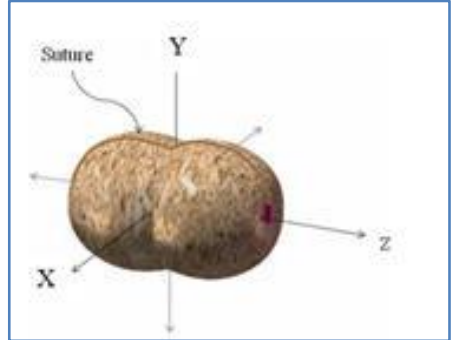

Fig-2: Representation of the Three Orientations of the Groundnut Kernel

Source: Bagheri et al. [22]

\section{Experimental Design and statistical analysis}

A $3 \times x \quad 3 \quad x \quad 3$ factorial experiment in a randomized complete block design (RCBD) was employed to this study. The three loading rates, three loading orientations and three kernels sizes were the main factors of the experiment. The loading rate range (15 $\mathrm{mm} / \mathrm{min}-25 \mathrm{~mm} / \mathrm{min})$ and loading orientations were selected based on a literature review [12, 22, 27] and initial laboratory tests. The data obtained from this study were subjected to statistical analysis using the Statistical Package for Social Statistics (SPSS version 20), and Duncan's Multiple Range Test (DMRT) was used to compare the mean at $(\mathrm{p} \leq 0.05)$.

\section{RESULTS AND DISCUSSION}

The Analysis of variance (ANOVA) of the effects of loading rate, kernel size and loading orientation on the mechanical behaviours of the groundnut kernels are presented in Table 3. As shown in Table 3, loading rate, loading orientation and kernel size had a significant effect on the rupture force, toughness and power of the groundnut kernel at 95 percent confidence level. The average values of rupture force, at different loading rates, kernel sizes and loading orientations with their Duncan's Multiple Range Test are presented in Table 4.

Table-3: ANOVA table of effects loading rate, kernel size and loading orientation on the mechanical behaviours of the groundnut kernels

\begin{tabular}{|c|c|c|c|c|c|}
\hline Source of variation & df & Rupture force & Rupture energy & Toughness & Rupture power \\
\hline L & 2 & $1.58 \mathrm{E}-36^{*}$ & $6.77 \mathrm{E}-03^{*}$ & $1.67 \mathrm{E}-35^{*}$ & $3.99 \mathrm{E}-15^{*}$ \\
\hline O & 2 & $1.61 \mathrm{E}-26^{*}$ & $0.23447^{\mathrm{ns}}$ & $1.05 \mathrm{E}-16^{*}$ & $5.10 \mathrm{E}-15^{*}$ \\
\hline S & 2 & $5.87 \mathrm{E}-32^{*}$ & $0.13769^{\mathrm{ns}}$ & $1.51 \mathrm{E}-37^{*}$ & $6.16 \mathrm{E}-14^{*}$ \\
\hline L x O & 4 & $7.34 \mathrm{E}-08^{*}$ & $0.38234^{\mathrm{ns}}$ & $1.01 \mathrm{E}-15^{*}$ & $4.43 \mathrm{E}-03^{*}$ \\
\hline L x S & 4 & $2.16 \mathrm{E}-06^{*}$ & $0.35912^{\mathrm{ns}}$ & $8.54 \mathrm{E}-25^{*}$ & $0.58449^{\mathrm{ns}}$ \\
\hline S x O & 4 & $3.09 \mathrm{E}-02^{*}$ & $0.38277^{\mathrm{ns}}$ & $1.08 \mathrm{E}-03^{*}$ & $2.34 \mathrm{E}-03^{*}$ \\
\hline L x O x S & 8 & $9.68 \mathrm{E}-02^{*}$ & $0.29506^{\mathrm{ns}}$ & $9.66 \mathrm{E}-20^{*}$ & $9.59 \mathrm{E}-04^{*}$ \\
\hline
\end{tabular}

$\mathrm{L}=$ loading rate $\mathrm{O}=$ orientation; $\mathrm{S}=$ size $; *=$ significant at $\mathrm{p} \leq 0.05 ; \mathrm{ns}=$ non-significant 
Table-4: Effects of loading rate, size and loading orientation on rupture force, rupture energy, toughness and rupture power of SAMNUT 11 kernels

\begin{tabular}{|c|c|c|c|c|c|c|}
\hline $\begin{array}{c}\text { Loading } \\
\text { rate }\end{array}$ & size & Orientation & $\begin{array}{l}\text { Rupture force } \\
\text { (N) }\end{array}$ & $\begin{array}{c}\text { Rupture energy } \\
(\mathrm{J})\end{array}$ & $\begin{array}{l}\text { Toughness } \\
\left(\mathbf{m J} / \mathbf{m m}^{3}\right)\end{array}$ & Power (W) \\
\hline \multirow[t]{9}{*}{25} & Large & $\mathrm{X}$-axis & $45.00^{\mathrm{a}}(4.88)$ & $0.053^{\mathrm{a}}(0.004)$ & $0.024^{c}(0.001)$ & $0.114^{\mathrm{b}}(0.007)$ \\
\hline & & Y-axis & $34.93^{\mathrm{b}}(2.99)$ & $0.042^{\mathrm{a}}(0.005)$ & $0.018^{\mathrm{b}}(0.001)$ & $0.116^{\mathrm{a}}(0.002)$ \\
\hline & & Z-axis & $31.42^{\mathrm{C}}(1.40)$ & $0.035^{\mathrm{a}}(0.006)$ & $0.015^{\mathrm{a}}(0.003)$ & $0.105^{\mathrm{C}}(0.011)$ \\
\hline & Medium & $\mathrm{X}$-axis & $35.37^{\mathrm{a}}(4.20)$ & $0.042^{\mathrm{a}}(0.004)$ & $0.051^{\mathrm{c}}(0.004)$ & $0.108^{\mathrm{b}}(0.003)$ \\
\hline & & Y-axis & $29.05^{\mathrm{b}}(1.84)$ & $0.032^{\mathrm{a}}(0.001)$ & $0.039^{\mathrm{b}}(0.001)$ & $0.104^{\mathrm{a}}(0.003)$ \\
\hline & & Z-axis & $23.28^{\mathrm{c}}(1.89)$ & $0.027^{\mathrm{a}}(0.001)$ & $0.033^{\mathrm{a}}(0.001)$ & $0.099^{\mathrm{c}}(0.003)$ \\
\hline & Small & $\mathrm{X}$-axis & $23.80^{\mathrm{a}}(1.52)$ & $0.029^{\mathrm{a}}(0.002)$ & $0.083^{\mathrm{c}}(0.006)$ & $0.104^{\mathrm{b}}(0.008)$ \\
\hline & & Y-axis & $17.52^{\mathrm{b}}(2.45)$ & $0.024^{\mathrm{a}}(0.003)$ & $0.070^{\mathrm{b}}(0.007)$ & $0.090^{\mathrm{C}}(0.009)$ \\
\hline & & Z-axis & $13.01^{\mathrm{c}}(1.18)$ & $0.020^{\mathrm{a}}(0.002)$ & $0.059^{\mathrm{a}}(0.006)$ & $0.076^{\mathrm{a}}(0.007)$ \\
\hline \multirow[t]{9}{*}{20} & Large & $\mathrm{X}$-axis & $77.49^{\mathrm{a}}(2.86)$ & $0.093^{\mathrm{ab}}(0.005)$ & $0.044^{\circ}(0.002)$ & $0.125^{\mathrm{b}}(0.011)$ \\
\hline & & Y-axis & $59.46^{\mathrm{b}}(5.98)$ & $0.079^{\mathrm{ab}}(0.008)$ & $0.037^{\mathrm{b}}(0.004)$ & $0.122^{\mathrm{c}}(0.004)$ \\
\hline & & Z-axis & $49.03^{\mathrm{c}}(7.08)$ & $0.059^{\mathrm{ab}}(0.015)$ & $0.028^{\mathrm{a}}(0.007)$ & $0.087^{\mathrm{a}}(0.019)$ \\
\hline & Medium & $\mathrm{X}$-axis & $55.31^{\mathrm{a}}(4.33)$ & $0.072^{\mathrm{ab}}(0.008)$ & $0.087^{\circ}(0.009)$ & $0.116^{\mathrm{b}}(0.009)$ \\
\hline & & Y-axis & $36.28^{\mathrm{b}}(3.96)$ & $0.045^{\mathrm{ab}}(0.004)$ & $0.054^{b}(0.005)$ & $0.093^{\mathrm{c}}(0.004)$ \\
\hline & & Z-axis & $34.63^{\mathrm{c}}(3.81)$ & $0.042^{\mathrm{ab}}(0.005)$ & $0.050^{\mathrm{a}}(0.006)$ & $0.093^{\mathrm{a}}(0.008)$ \\
\hline & Small & $\mathrm{X}$-axis & $37.41^{\mathrm{a}}(4.26)$ & $0.047^{\mathrm{ab}}(0.005)$ & $0.030^{c}(0.016)$ & $0.112^{\mathrm{b}}(0.006)$ \\
\hline & & Y-axis & $29.11^{\mathrm{b}}(2.04)$ & $0.033^{\mathrm{ab}}(0.004)$ & $0.094^{\mathrm{b}}(0.012)$ & $0.086^{\circ}(0.004)$ \\
\hline & & Z-axis & $23.10^{\mathrm{c}}(2.62)$ & $0.028^{\mathrm{ab}}(0.001)$ & $0.082^{\mathrm{a}}(0.002)$ & $0.082^{\mathrm{a}}(0.002)$ \\
\hline \multirow[t]{9}{*}{15} & Large & $\mathrm{X}$-axis & $94.31^{\mathrm{a}}(4.72)$ & $0.116^{\mathrm{b}}(0.007)$ & $0.055^{\mathrm{c}}(0.003)$ & $0.095^{\mathrm{b}}(0.002)$ \\
\hline & & Y-axis & $78.63^{\mathrm{b}}(0.66)$ & $0.093^{\mathrm{b}}(0.002)$ & $0.044^{b}(0.001)$ & $0.090^{\mathrm{C}}(0.003)$ \\
\hline & & Z-axis & $62.69^{\circ}(2.95)$ & $0.083^{\mathrm{b}}(0.006)$ & $0.040^{\mathrm{a}}(0.003)$ & $0.092^{\mathrm{a}}(0.004)$ \\
\hline & Medium & $\mathrm{X}$-axis & $80.22^{\mathrm{a}}(2.10)$ & $0.096^{\mathrm{b}}(0.005)$ & $0.116^{c}(0.006)$ & $0.092^{\mathrm{b}}(0.001)$ \\
\hline & & Y-axis & $61.86^{\mathrm{b}}(3.30)$ & $0.632^{\mathrm{b}}(0.024)$ & $0.100^{\mathrm{b}}(0.009)$ & $0.089^{\mathrm{c}}(0.001)$ \\
\hline & & Z-axis & $44.12^{\mathrm{c}}(3.36)$ & $0.054^{\mathrm{b}}(0.005)$ & $0.066^{\mathrm{a}}(0.006)$ & $0.072 \mathrm{a}(0.004)$ \\
\hline & Small & $\mathrm{X}$-axis & $60.45^{\mathrm{a}}(1.49)$ & $0.081^{\mathrm{b}}(0.005)$ & $0.233^{\mathrm{c}}(0.015)$ & $0.089^{\mathrm{b}}(0.002)$ \\
\hline & & Y-axis & $42.48^{\mathrm{b}}(1.96)$ & $0.051^{b}(0.006)$ & $0.147^{b}(0.016)$ & $0.070^{\mathrm{C}}(0.004)$ \\
\hline & & Z-axis & $36.14^{\mathrm{C}}(3.56)$ & $0.044^{\mathrm{b}}(0.002)$ & $0.127^{\mathrm{a}}(0.006)$ & $0.068^{\mathrm{a}}(0.003)$ \\
\hline
\end{tabular}

Standard deviation values are in the parenthesis; in the same column, means with the same common letters in superscripts are not significantly different $(\mathrm{P} \leq 0.05)$ using Duncan's Multiple Range Test

\section{Effect of loading rate, loading orientation and kernel size on the rupture force}

From the data in Table 4, the average force required to rupture the kernels decreased with an increase in loading rate, and decreased in the sizes of the kernel. On the average, large kernels required about $38 \%$ greater force to rupture when compared with the small kernels, in the three axes tested. The highest rupture force $(94.31 \mathrm{~N})$ was obtained for the large kernel on the X-axis at the loading rate of $15 \mathrm{~mm} / \mathrm{min}$. Similar results were obtained by Ince et al. [28] and Ijabo et al. [16] for groundnut (other culivars) and bambara nut. According to Ijabo et al. [16], a cracking force of $45.13 \mathrm{~N}$ was recorded when a groundnut (local cultivar) kernel was loaded along the plane containing the suture line (helium position). In addition, Ijabo et al. [16] reported a cracking force of $34.80 \mathrm{~N}$ for Bambara nut, when loaded along the plane containing the suture line, at a moisture content of $4.6 \%$ (dry basis). Ince et al. [28] reported that the highest rupture force $(122.76$ $\mathrm{N}$ ) was observed when a peanut kernel was loaded along the $\mathrm{X}$ - axis (the plane perpendicular to the suture line). The disparities in the rupture (cracking/fracture) force obtained for the groundnut can be attributed to local climatic condition, soil condition, harvesting period, farming method and the groundnut cultivar. According to Iweka and Uguru [6] and Uguru et al. [9], the mechanical properties of agricultural products are highly dependent on the crop cultivar, farming method employed during the growing period, harvesting time, storage and processing condition, the local climate of the region, maturity stage of the crop, and insect and pests attacks on the crops. Demir et al. [29] observed significant difference on some engineering properties of tomato (Lycopersicon esculentum) planted under different environmental conditions. Furthermore, Kilickan and Guner [30] reported that the rupture force of the olive fruit increased in magnitude with an increase in fruit size. Bahrami et al. [31], stated that the force required initiating Oak marble galls rupture along the $\mathrm{Y}$ and $\mathrm{X}$ axes were as $236.44 \mathrm{~N}$ and $201.78 \mathrm{~N}$, respectively. On the contrary Olaniyan and Oje [25] reported that the rupture force of shea butternut was lower in axial loading position $(68.647 \mathrm{~N})$, when compared with lateral loading position (89.103 N). Rupture force of nuts and kernels is an essential 
parameter in the design and development of their milling and crushing machines. Size reduction is an essential unit operation during food processing.

\section{Effect of loading rate, loading orientation and kernel size on rupture energy}

The experimental results showed that the rupture energy of the kernels was highly dependent in its axis, loading rate and kernels sizes (Table 4). The greatest rupture energy required to rupture the kernels were recorded along the $\mathrm{X}$-axis $(0.116 \mathrm{Nm})$, for the large kernels, at the loading rate of $15 \mathrm{~mm} / \mathrm{min}$. These results are similar to previous results obtained by Ijabo et al. [16] for bambara nut and groundnut. According to Ijabo et al. [16], an average failure energy of 0.0008 $\mathrm{Nm}$ and $0.00945 \mathrm{Nm}$ were recorded when groundnut kernel and bambara nut were loaded along the plane containing the suture line, at a moisture content of $5.5 \%$ and $4.6 \%$ (dry basis) respectively. These result obtained by Ijabo et al. [16] was much lower when compared to our result $(0.093 \mathrm{Nm})$. These differences could be attributed to the loading speed, crop type, loading rate, moisture content, kernel size and mechanical testing condition (sensitivity of the machine, temperature and relative humidity). Kilickan and Guner [30] stated that the rupture energy of the olive fruit increased in magnitude with an increase in deformation rate and size. According to their results, the fruit $\mathrm{X}$-axis recorded the highest rupture energy $(0.32$ $\mathrm{Nm})$, while the $\mathrm{Y}$-axis recorded the lowest energy $(0.26$ $\mathrm{Nm}$ ). Braga et al. [21] studied the effects of nut size and loading position on the force, specific deformation and energy required for the initial rupturing of macadamia nut shell under compression. Their results showed that there is a particular compression position at which the force, specific deformation and energy values are minimal, independent of nut size and shell moisture. Furthermore, the results of Oghenerukevwe and Uguru [27] on mechanical properties of gmelina fruit showed that the rupture energy of the gmelina fruit under vertical loading was lower than under horizontal loading, and as the gmelina fruit size increased from small to large, its average rupture energy increased from $0.899 \mathrm{Nm}$ to $1.475 \mathrm{Nm}$.

\section{Effect of loading rate, loading orientation and kernel size on Toughness}

From the results, the toughness of groundnut kernels decreased along the $\mathrm{X}, \mathrm{Y}$ and $\mathrm{Z}$ - axes in the three loading rates. Additionally, the toughness decreased with an increase in kernels size across its three axes; in a relationship that was significant at a 95\% confidence level. The kernels toughness at the Xaxis was highest among the three axes (Table 4), portraying that more energy was absorbed by the kernels at the $\mathrm{X}$-axis before they ruptured. The higher values of the toughness of smaller kernels than larger kernels can be attributed to their body mass and density differences. According to Fricke and Wright [32], small seeds usually had the highest tissue densities across all crops species; therefore, seed toughness strongly decreases as its mass increases. In research into mechanical properties of 70 species of crops and trees seeds, Fricke and Wright [32] reported that smaller seeds had higher specific toughness (2340 times greater) than larger seeds, in one of their measures. Similarly, Ahmet Ince et al. [28] reported that peanut kernel toughness increased from 0.022 to 0.032 $\mathrm{mJ} / \mathrm{mm}^{3}$ as the kernel size decreased from large to small size.

\section{Effect of loading rate, loading orientation and kernel size on the rupturing power}

From the ANOVA table, the kernels size and loading rate had a significant effect $(\mathrm{P} \leq 0.05)$ on the rupturing power of the groundnut kernels. The values of rupture power values of the kernels presented in Table 4 shows that, the $\mathrm{X}$ - axis had the highest value than those for both the Y-and Z-axis. According to Altuntas et al. [11], the power required to crack almond nut measured while loading along $\mathrm{X}$ - axis ranged from $0.20 \mathrm{~W}$ to 0.73 $\mathrm{W}$ 'Nonpareil', $0.20 \mathrm{~W}$ to $0.67 \mathrm{~W}$ 'Picantili' and 0.18 $\mathrm{W}$ to $0.65 \mathrm{~W}$ 'Drake' cultivar, respectively. Furthermore, Khazaei et al. [33] reported the rupturing power required rupturing an almond increased with increasing almond dimension, but the difference was not significant between big and medium almonds. Results obtained from this study showed that loading rate, the kernels orientation and size of groundnut kernels should be considered while designing groundnut processing machine. Based on the findings of this study, it is will be better to mill the groundnut kernels higher speed (loading rate), to conserve energy and power during the million operations. In addition, it can be seen from the results that the smaller kernel will consume lower power during groundnut oil production, when compared to the larger groundnut kernels.

\section{CONCLUSION}

In this study, the effect of loading rate, kernel orientation and kernel size on the mechanical behaviour of groundnut kernels "cv. SAMNUT 11" was investigated. The results obtained from the study indicated that the rupture force, rupture energy, toughness and rupture power were significantly dependent on the compression loading rate. According to the results, the rupture force, rupture energy and rupture power of the groundnut kernels increased with decrease in the loading rate. From the above results, the rupture force increased with increase in the size of the kernel; but decreased with decrease in the size of the kernel. In addition, the force energy required at rupture point for large-size groundnut kernels were higher in the $\mathrm{X}$ - axis than in the $\mathrm{Y}$-axis and $\mathrm{Z}$ - axis. The toughness of the groundnut kernels increased in decrease in the size of the kernel, when tested using all the compression axes Furthermore, greater power was required to rupture large groundnut kernels in the three axes tested in this study. Based on the findings of this study, it is will be better to mill the groundnut kernels 
higher speed (loading rate), to conserve energy and power during the milling operations

\section{REFERENCES}

1. FAO. FAOSTAT database. World groundnut production. 2019.Available

at: http://www.fao.org/faostat/en/\#data/QC

2. Ndjeunga J, Ntare BR, Ajeigbe HA, Echekwu CA, Ibro A, Amadou A. Adoption and impacts of modern groundnut varieties in Nigeria.

3. Ajeigbe HA, Waliyar F, Echekwu CA, Ayuba K, Motagi BN, Eniayeju D, Inuwa A. A Farmer's guide to groundnut production in Nigeria. Patancheru. 2014;502(324):36.

4. Akpokodje OI, Uguru H. Impact of farming methods on some anti-nutrients, nutrients and toxic substances of cassava roots. Int. J. Sci. Res. Sci. Eng. Technol. 2019;6(4):275-84.

5. Gepts P, Beavis WD, Brummer EC, Shoemaker RC, Stalker HT, Weeden NF, Young ND. Legumes as a model plant family. Genomics for food and feed report of the cross-legume advances through genomics conference.

6. Uguru $\mathrm{H}$, Nyorere $\mathrm{O}$. Failure behaviour of groundnut (SAMNUT 11) kernel as affected by kernel size, loading rate and loading position. International Journal of Scientific \& Engineering Research. 2019;10(2):1209-17.

7. Malik MA, Saini CS. Engineering properties of sunflower seed: Effect of dehulling and moisture content. Cogent Food \& Agriculture. 2016 Dec 31;2(1):1145783.

8. Niklas KJ. Plant biomechanics: an engineering approach to plant form and function. University of Chicago press.1992.

9. Uguru H, Nyorere O. Failure behaviour of groundnut (SAMNUT 11) kernel as affected by kernel size, loading rate and loading position. International Journal of Scientific \& Engineering Research. 2019;10(2):1209-17.

10. Bargale PC, Irudayaraj J, Marquis B. Studies on rheological behaviour of canola and wheat. Journal of Agricultural Engineering Research. 1995 Aug 1;61(4):267-74.

11. Altuntas E, Gercekcioglu R, Kaya C. Selected mechanical and geometric properties of different almond cultivars. International Journal of Food Properties. 2010 Feb 24;13(2):282-93.

12. Güner M, Dursun E, Dursun IG. Mechanical behaviour of hazelnut under compression loading. Biosystems Engineering. 2003 Aug 1;85(4):48591.

13. Altuntaş E, Somuncu C, Ozturk B. Mechanical behaviour of plum fruits as affected by preharvest methyl jasmonate applications. Agricultural Engineering International: CIGR Journal. 2013 Jul 1;15(2):266-74.

14. Sadowska J, Jeliński T, Błaszczak W, Konopka S, Fornal J, Rybiński W. The effect of seed size and microstructure on their mechanical properties and frictional behavior. International journal of food properties. 2013 May 19;16(4):814-25.

15. Uyeri C, Uguru H. Compressive Resistance of Groundnut Kernels as Influenced by Kernel Size. Journal of Engineering Research and Reports. 2018:1-7.

16. Ijabo OJ, Orwua JT, Omale PA. Determination of Quasi-Static Behaviour of Bambara Nut, Ground Nut and African Yam Beans Pods and Seeds. 2016.

17. AOAC. Official Methods of Analysis of AOAC INTERNATIONAL, 21st Edition. Association Official Analytical Chemists, Washington, DC., USA. 2019.

18. Uguru H, Akpokodje OI, Irtwange SV. Mechanical Behaviour of Common Bean (cv. Butter) Seeds as Affected by Maturation. Journal of Engineering Research and Reports. 2019 Nov 22:1-2.

19. Eboibi O, Uguru H. Storage conditions effect on physic-mechanical properties of Nandini cucumber. International Journal of Engineering and Technical Research. 2017;7(10).

20. ASABE. American Society of Agricultural and Biological Engineers: Chicago, IL, 2008.

21. Braga GC, Couto SM, Hara T, Neto JT. Mechanical behaviour of macadamia nut under compression loading. Journal of Agricultural Engineering Research. 1999 Mar 1;72(3):239-45.

22. Bagheri I, Payman SH, Rahimi-Ajdadi F. Mechanical behavior of peanut kernel under compression loading as a function of moisture contents. Elixir Agriculture. 2011 Jul 8;36:3552-7.

23. Łysiak G. Fracture toughness of pea: Weibull analysis. Journal of food engineering. 2007 Dec $1 ; 83(3): 436-43$.

24. Steffe JF. Rheological methods in food process engineering. Freeman press; 1996.

25. Olaniyan AM, Oje K. Strength properties of sheabutter nuts under compressive loading. Nigerian Journal of Technology. 2002;21(1):9-17.

26. Eboibi O, Akpokodje OI, Uguru H. Growth performance of five bean (Phaseolus spp) varieties as influenced by organic amendment. Journal of Applied Sciences and Environmental Management. 2018;22(5):759-63.

27. Oghenerukevwe PO, Uguru H. Effect of fruit size and orientation on mechanical properties of gmelina fruit (Gmelina arborea) under quasi-Static loading. International Journal of Engineering and Technical Research. 2018;8(4):47-51.

28. Ince A, Ugurluay S, Güzel E, Özcan MT. Mechanical behavior of hulled peanut and its kernel during the shelling process. Philippine Agricultural Scientist. 2009 Mar 12;92(1):92-9.

29. Demir I, Ashirov AM, Mavi K. Effect of Seed Production Environment and Time of Harvest on Tomato(Lycopersicon esculentum) Seedling Growth. Research Journal of Seed Science. 2010 Jul;3(3):160-9.

30. Kilıçkan A, Güner M. Physical properties and mechanical behavior of olive fruits (Olea europaea 
L.) under compression loading. Journal of Food Engineering. 2008 Jul 1;87(2):222-8.

31. Bahrami M, Lorestani AN, Jaliliantabar F, Gholami R. Physical and mechanical properties and mass modeling of Oak marble galls (Andricus kollari) based on geometric attributes. International Journal of Agricultural Technology. 2012;8(6):1881-93.
32. Fricke EC, Wright SJ. The mechanical defence advantage of small seeds. Ecology letters. 2016 Aug;19(8):987-91

33. Khazaei J, Rasekh M, Borghei AM. Physical and Mechanical Properties of Almond and its Kernel related to cracking and peeling. In 2002 ASAE Annual Meeting. American Society of Agricultural and Biological Engineers. 2002: 1. 